\title{
Some Factors Influencing Pregnancy Rate and Subsequent Litter Size in Primiparous Sows
}

\author{
By M. Sterning ${ }^{1}$ and N. Lundeheim ${ }^{2}$ \\ ${ }^{1}$ Department of Obstetrics and Gynaecology and ${ }^{2}$ Department of Animal Breeding and Genetics, Swedish Uni- \\ versity of Agricultural Sciences, Uppsala, Sweden.
}

\begin{abstract}
Sterning, M. and N. Lundeheim: Some factors influencing pregnancy rate and subsequent litter size in primiparous sows. Acta vet. scand. 1995, 36, 353-365. - The pregnancy rate and the subsequent litter size were studied in 332 Swedish Yorkshire primiparous sows, fed according to a commercial Swedish feeding regime during lactation. The sows were weighed and backfat depth was recorded at the first farrowing, at weaning, and at mating. Oestrous detection was performed once daily after weaning, and the interval from weaning to first oestrus (IWO) was recorded. Blood samples for determination of plasma progesterone were drawn regularly after the first weaning. Statistical analyses were only performed on sows with an IWO of 3-8 days. Of these 206 sows were mated on their first (OE1 sows) and 87 sows on their second ( 87 OE2 sows) oestrus after weaning.

The pregnancy rate was $85.4 \%$ for OE1 sows and $75.9 \%$ for OE2 sows $(\mathrm{p}=0.048)$. There was no significant difference in pregnancy rate between OE1 sows with an IWO of 3-5 days and OE1 sows with an interval of 6-8 days. OE2 sows with an IWO of 6-8 days, on the other hand, had a significantly lower pregnancy rate compared with OE2 sows with an interval of 3-5 days. The pregnancy rate in sows that lost more than $30 \mathrm{~kg}$ during the first lactation period did not differ from that of sows losing less than $30 \mathrm{~kg}$. In sows with a first litter size of more than 9 piglets alive at birth, the pregnancy rate decreases significantly if mating is delayed until the second oestrus after weaning.

OE2 sows had a significantly larger second litter size at birth than OE1 sows $(+2.0)$. The litter size at six weeks did not, on the other hand, differ significantly $(+0.4)$. There was a positive correlation between the IWO and 2nd litter size, although significant only for OE1 sows between the IWO and litter size alive at birth. In the OE1 group, sows losing $20 \mathrm{~kg}$ or less during lactation had significantly larger second litters at birth than the sows losing 21-30 kg, but not significantly larger than the sows losing more than $30 \mathrm{~kg}$. One piglet more, at birth, in the first litter resulted in 0.25 piglet more in the second litter. For sows with a large first litter there was a low probability of also having a large second litter.
\end{abstract}

swine; mating oestrus; weaning oestrus interval; weight loss; 1st litter size.

\section{Introduction}

Today's swine production needs to be highly efficient. It is important to reduce the number of anoestrus sows after weaning and to shorten the interval from weaning to oestrus. In a study on primiparous sows, Sterning et al. (1990) showed that large weight losses during lactation significantly reduced the ability to ovulate and show standing oestrus within 10 days of weaning in primiparous sows. Another study by Sterning et al. (1994) showed that daily boar contact after weaning in combination with reduced weight loss during lactation could increase the number of primiparous sows ovulating within 10 days of weaning. 


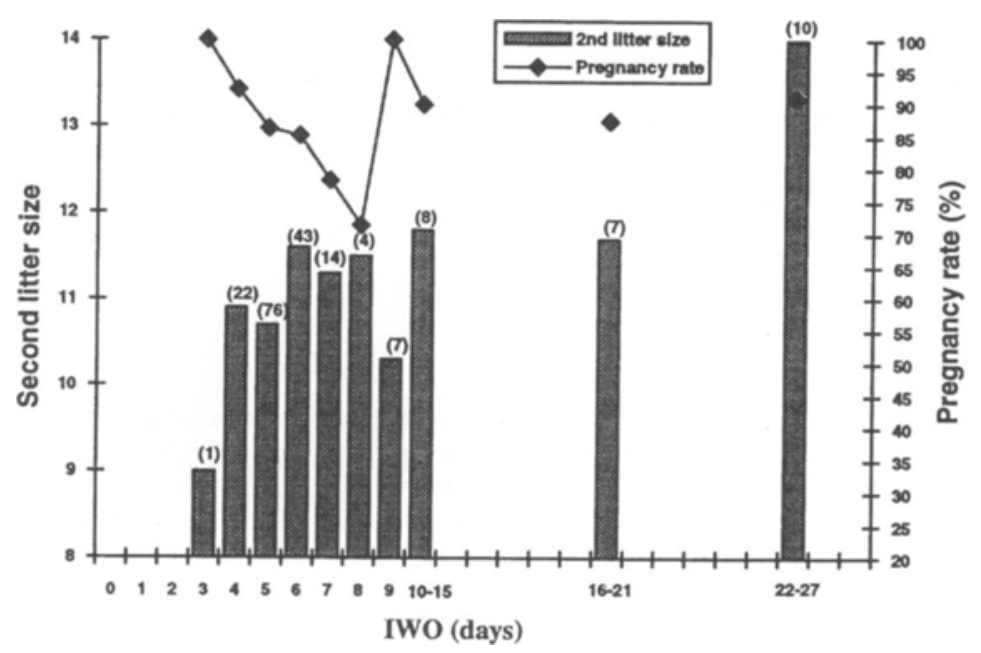

Figure 1. Primiparous sows mated on the first oestrus after weaning (OE1) and having different IWOs. Influences of IWO on mean second litter size at birth $(n=192)$ and on mean pregnancy rate $(n=242)$. The number of sows are given in brackets.

The same study also showed that careful oestrous detection using a boar and good knowledge of oestrous symptoms in primiparous sows could increase the number of sows with detected standing reflex at the first oestrus after weaning.

The efficiency in swine production could also be increased with higher farrowing rates and larger litter sizes. Earlier studies report that farrowing rates as well as litter sizes can be influenced by the weaning to breeding interval (Love 1979, Leman 1987, Wilson \& Dewey 1993). Wilson \& Dewey (1993) suggest that it might be economically advantageous to delay matings in sows that show oestrus in "less efficient intervals « from weaning to first oestrus until their second oestrus. In order to give the right advice to swine producers and to be able to make a cost-benefit analysis, it is of great importance to have good knowledge about the influence of the interval from weaning to first oestrus (IWO) and of mating oestrus on farrowing rates and subsequent litter size.
The purposes of this study were to study the pregnancy rate and subsequent litter size in Swedish Yorkshire primiparous sows mated for the first time on the first or the second oestrus after weaning. The influences of the interval from weaning to first oestrus (IWO), weight loss during lactation, and first litter size on farrowing rate and second litter size were also analysed.

\section{Materials and methods}

This study comprises observations in 332 purebred Swedish Yorkshire primiparous sows, all with a lactational length of 40-51 days. The animals belonged to a selection experiment carried out at a research station belonging to the Department of Animal Breeding and Genetics, Swedish University of Agricultural Sciences. Pigs from the first 4 generations were selected for high lean tissue growth rate $(25-90 \mathrm{~kg})$ at 2 different protein levels (2 selection lines) (Stern et al. 1993). Pigs from the last generation were 


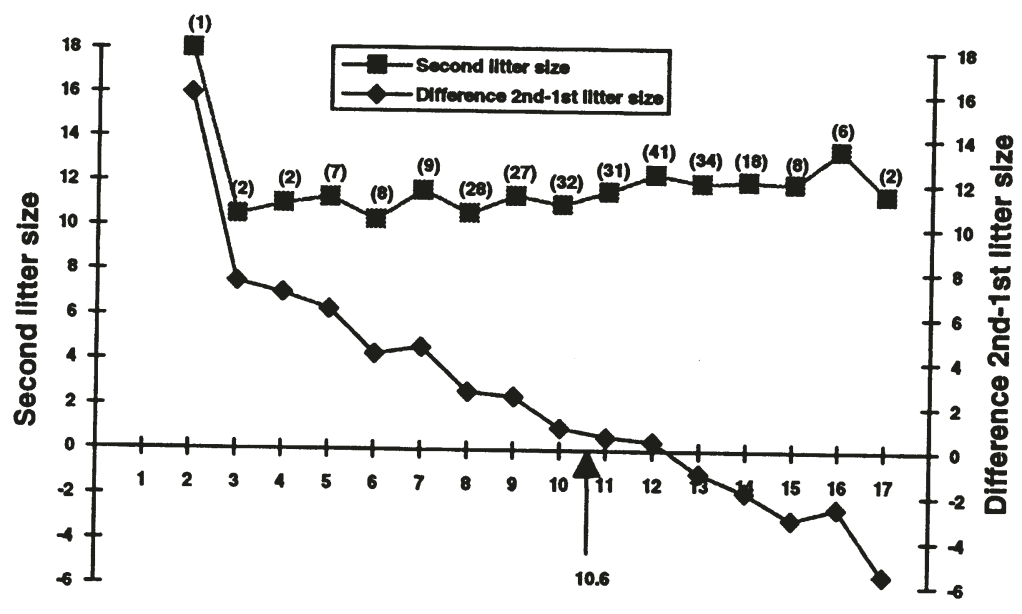

First litter size

Figure 2. Relationship between first litter size at birth and mean second litter size at birth as well as the mean difference between first and second litter size at birth in OE1 and OE2 sows $(n=256)$. The number of sows are given in brackets. The overall mean value for first litter size is marked with an arrow.

chosen at random and fed a standard diet (Stern et al. 1995). The animals were reared indoors and farrowed in batches. From $90 \mathrm{~kg}$ live weight, the gilts to be used for the next generation were fed $2.2 \mathrm{~kg} /$ day of a barley-based sow diet (12.1 $\mathrm{MJ} / \mathrm{kg}, 14.5 \%$ crude protein). During gestation, the gilts were kept indoors with 4 gilts in each pen. Three weeks before expected farrowing, the gilts were moved to individual farrowing pens. After weaning, the sows were immediately moved back to the gestation units where boars were always present. During gestation, the gilts were fed $2.2 \mathrm{~kg} /$ day of the sow diet. During lactation, the daily feed allowance was gradually increased from $2.0 \mathrm{~kg}$ at farrowing to a maximum of $2.0 \mathrm{~kg}+0.4 \mathrm{~kg}$ per piglet. After weaning, the daily feed intake was $4-5 \mathrm{~kg}$ until mating and thereafter $2.2 \mathrm{~kg}$.

The sows were weighed and ultrasonic measurement of the backfat was made within 2 days of the first farrowing and weaning (no sow was weighed before farrowing) and within 2 days of the day of mating after weaning. Measurement of the backfat was made at the last rib on both sides, approximately $8 \mathrm{~cm}$ from the middle of the back. The piglets from both the first and the second litter were weighed at birth and at three and six weeks of age.

From the day after weaning, oestrous detection was performed once daily, and the interval from weaning to first oestrus (IWO) was recorded.

Blood samples for determination of plasma progesterone were drawn either at 12 days after weaning, if no standing oestrus was recorded within 10 days of weaning, or 12 days after the onset of the first standing oestrus, if this occurred within 10 days of weaning. The level of plasma progesterone was determined using a radioimmunoassay system (Bosu et al. 1976) at the Department of Clinical Chemistry, Swedish University of Agricultural Sciences, Uppsala, Sweden. The system used was designed to cover a wide range of high progesterone levels, thereby partly sacrificing assay sensitivity. In this assay system a progesterone 
Table 1. Reproductive and production traits in OE1 and OE2 sows. The values for all sows, IWO 3-27 (overall mean values), as well as for the group of sows with an IWO of 3-8 days (least squares means, model 1) are presented.

\begin{tabular}{lrrrrr}
\hline & \multicolumn{2}{c}{ IWO 3-27 } & & \multicolumn{2}{c}{ IWO 3-8 } \\
\cline { 2 - 3 } \cline { 5 - 6 } & \multicolumn{1}{c}{ OE 1 } & \multicolumn{1}{c}{ OE2 } & & OE1 \\
\hline First litter size: & & & & \\
- at birth & $10.8(242)$ & $10.1(90)$ & & $10.8^{\mathrm{a}}(206)$ & $10.1^{\mathrm{a}}(87)$ \\
- alive at birth & $9.8(242)$ & $9.1(90)$ & & $9.8^{\mathrm{a}}(206)$ & $9.0^{\mathrm{b}}(87)$ \\
- at three weeks & $9.0(242)$ & $8.2(90)$ & & $9.0^{\mathrm{a}}(206)$ & $7.9^{\mathrm{b}}(87)$ \\
- at six weeks & $8.8(242)$ & $8.2(90)$ & & $8.9^{\mathrm{a}}(206)$ & $7.9^{\mathrm{b}}(87)$ \\
& & & & \\
First litter weight gain $(\mathrm{kg}):$ & & & & \\
- 0-3 weeks & $41.7(234)$ & $39.4(90)$ & & $42.0^{\mathrm{a}}(198)$ & $37.9^{\mathrm{b}}(87)$ \\
- 0-6 weeks & $85.7(234)$ & $82.0(90)$ & & $86.3^{\mathrm{a}}(198)$ & $80.3^{\mathrm{b}}(87)$ \\
Age at weaning (days) & $479.1(242)$ & $461.6(90)$ & & $474.6^{\mathrm{a}}(206)$ & $462.7^{\mathrm{b}}(87)$ \\
Weight loss during & $33.3(242)$ & $29.2(90)$ & & $32.1^{\mathrm{a}}(206)$ & $27.6^{\mathrm{b}}(87)$ \\
lactation (kg) & & & & \\
Backfat loss during & $8.5(241)$ & $7.5(89)$ & & $8.5^{\mathrm{a}}(205)$ & $6.9^{\mathrm{b}}(86)$ \\
lactation (mm) & & & & \\
Weight at mating (kg) & $171.0(241)$ & $181.4(89)$ & $168.9^{\mathrm{a}}(206)$ & $185.0^{\mathrm{b}}(86)$ \\
Backfat at mating (mm) & $15.6(158)$ & $17.4(45)$ & & $15.7^{\mathrm{a}}(142)$ & $17.3^{\mathrm{b}}(44)$ \\
IWO (days) & $7.1(242)$ & $5.6(90)$ & $5.5^{\mathrm{a}}(206)$ & $5.2^{\mathrm{a}}(87)$ \\
\hline
\end{tabular}

ab Values with no superscript in common, within row, differ significantly $(\mathrm{p} \leq 0.05)$.

Figures in brackets indicate the number of sows.

IWO = interval from weaning to first oestrus (dogs).

$\mathrm{OE}=$ mating oestrus (1st or 2 nd oestrus after weaning).

concentration $7 \mathrm{nmol} / 1$ indicates active luteal tissue in the ovaries.

The selection experiment was not designed to study the effects of mating on different oestrouses after weaning. The sows in each batch $(n=32)$ were weaned during a four-week period. Weanings occurred on Mondays, Wednesdays and Fridays. Sows with serious leg weakness or other diseases like abscesses in the mammary glands were slaughtered immediately after weaning. The remaining sows were mated if they showed oestrus during the four-week mating period, which, due to the design of the selection experiment, started 2 weeks after the beginning of the weaning period. The sows were mated on the first detected oestrus during the mating period. Most of the sows were mated on the first oestrus af- ter weaning (OE1 $n=242$ ), whereas about one third of the primiparous sows were mated for the first time on the second oestrus after weaning (OE2 $n=90$ ). The sows were naturally mated 2 times with the same boar during oestrus. Sows mated on the first oestrus after weaning (OE1) had larger weight losses during the first lactation than sows mated on the second oestrus (OE2) (Table 1). This can be explained by the design of the selection experiment. Sows, weaned early during the weaning period and showing oestrus rapidly, were not mated on the first oestrus, as the mating period had not yet started. We know from earlier studies (Sterning et al. 1990) that larger weight losses results in longer IWO. Therefore, more sows with larger weight losses and longer IWOs were mated on the 
Table 2. Influences of IWO, of weight loss during first lactation and of first litter size on the pregnancy rate in OE1 and OE2 primiparous sows with an IWO of 3-8 days. The levels of significance were tested using the Chi-square test.

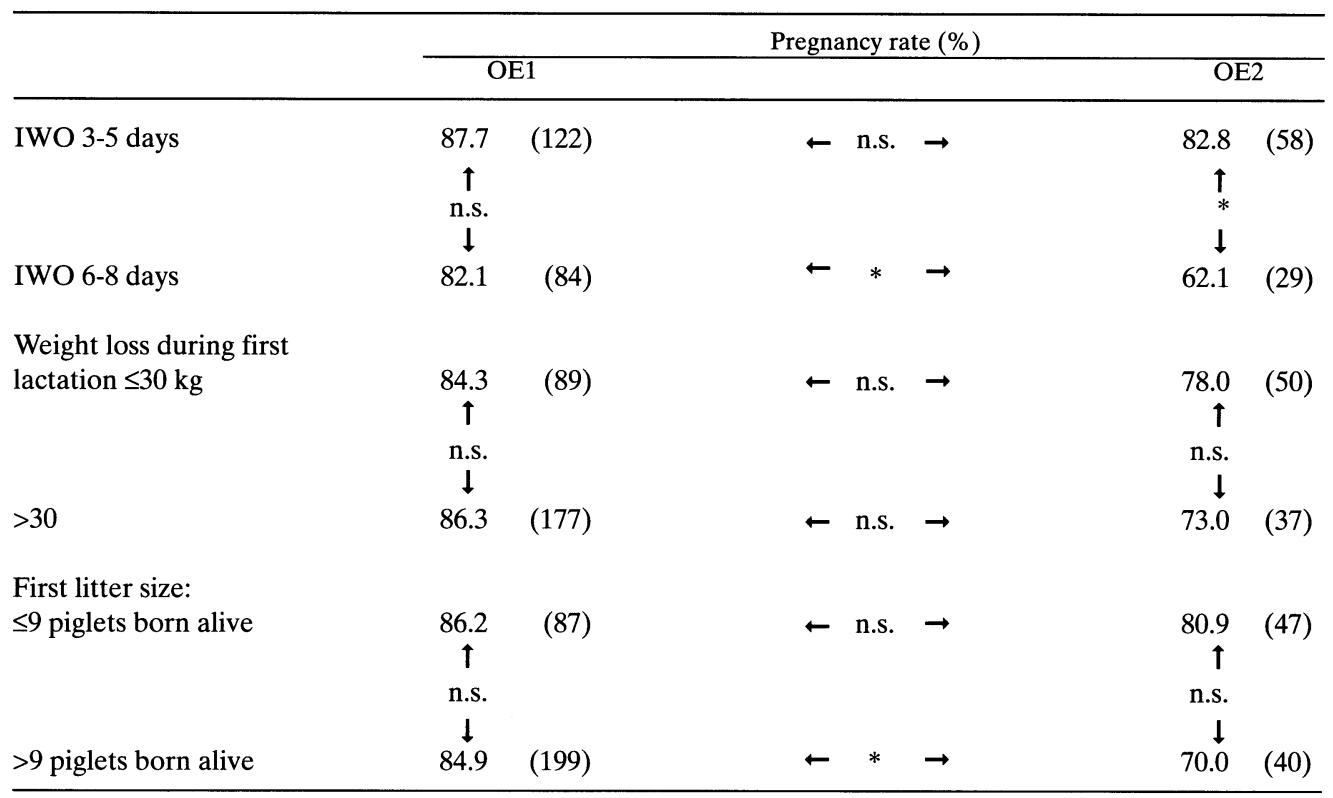

Figures in brackets indicate the number of sows.

For abbreviations see Table 1.

first oestrus after weaning than sows with smaller weight losses and shorter IWO. Sixteen sows, out of the 32 sows in each batch, were kept and farrowed a second time.

Only sows mated for the first time on their first or second oestrus after weaning were included in the study. Sows not showing standing oestrus at the first ovulation were excluded from the analyses. Sows with an interval between first and second oestrus exceeding 28 days were excluded due to the fact that they may have had an ovulation without standing reflex between these 2 occasions.

A sow was defined as pregnant if she fulfilled one of the following criteria:

a) delivered a second litter at the estimated time;

b) was examined for pregnancy around 4 weeks after mating with a positive result; c) aborted foetuses before expected farrowing;

d) had foetuses in the uterus at slaughter.

If a sow was slaughtered pregnant and the foetuses were counted this was defined as the total number of piglets born in the litter. For some sows that farrowed, information on litter size at 3 and 6 weeks were not recorded.

The number of piglets alive at birth was defined as the total number of piglets born minus mummies, stillborn and piglets that died on the day of farrowing and the day after.

\section{Statistical analyses}

The statistical analyses were performed using the Statistical Analyses System (SAS Institute Inc. 1985). Batches with few observations were grouped together. The decision about which effects would be included in the model 
Table 3. Least squares means for second litter size in OE1 and OE2 sows with an IWO of 3-8 days (model 3) and in OE1 and OE2 sows in different IWO classes (model 4).

\begin{tabular}{|c|c|c|c|c|c|}
\hline \multirow[b]{2}{*}{ IWO (days) } & \multicolumn{2}{|c|}{ OE1 } & \multicolumn{2}{|c|}{$\mathrm{OE} 2$} & \multirow{2}{*}{$\frac{\mathrm{OE} 2-\mathrm{OE} 1}{3-8}$} \\
\hline & $3-5$ & $6-8$ & $3-5$ & $6-8$ & \\
\hline \multicolumn{6}{|c|}{ Second liter size: } \\
\hline - at birth & $10.7^{\mathrm{a}}(99)$ & $11.5^{\mathrm{ac}}(61)$ & $12.8^{\mathrm{b}}(45)$ & $12.9^{\mathrm{bc}}(18)$ & $2.0 * * *$ \\
\hline - alive at birth & $9.4^{\mathrm{a}}(82)$ & $10.7^{\mathrm{b}}(47)$ & $10.5^{\mathrm{b}}(40)$ & $11.5^{\mathrm{b}}(14)$ & $0.9^{\text {n.s. }}$ \\
\hline - at 3 weeks & $8.8^{\mathrm{a}}(82)$ & $10.1^{\mathrm{bc}}(46)$ & $9.7^{\mathrm{ac}}(40)$ & $10.2^{\mathrm{ac}}(14)$ & $0.6^{\text {n.s. }}$ \\
\hline - at 6 weeks & $8.7^{\mathrm{a}}(82)$ & $10.1^{b c}(45)$ & $9.4^{\mathrm{ac}}(38)$ & $10.1^{\mathrm{ac}}(12)$ & $0.4^{\text {n.s. }}$ \\
\hline
\end{tabular}

abc Values with no superscript in common, within row, differ significantly ( $\mathrm{p} \leq 0.05)$.

Figures in brackets indicate the number of sows.

For abbreviations see Table 1.

was based on the results of the preliminary analyses. The range of IWOs among both OE1 and OE2 sows was 3 to 27 days, but only 3 OE2 sows had an IWO of more than 8 days. All statistical analyses were therefore performed only on sows with an IWO of 3 to 8 days $(n=293)$.

The following statistical models were used for the analyses of the data:

Model 1: including the effects of batch $(n=15)$, selection line $(n=2)$ and mating oestrus (OE1 or OE2);

Model 2: model 1, plus also including the effect of pregnancy (pregnant or non-pregnant) and the interaction between mating oestrus and pregnancy;

Model 3: model 1, plus the effects of the regression on weight loss during the first lactation and regression on first litter size, alive at birth; Model 4: model 1, plus the effects of IWO, classified as follows 1) 3-5 days; 2) 6-27 days and the interaction between mating oestrus and class of IWO;

Model 5: model 1, plus the effects of weight loss during the first lactation, classified as follows 1) $\leq 20 \mathrm{~kg}$; 2) $21-30 \mathrm{~kg}$; 3) $31-40 \mathrm{~kg}$; 4) >40 $\mathrm{kg}$, and the interaction between mating oestrus and class of weight loss;

Model 6: model 1, plus the regression on the total number of piglets born in the first litter. Spearman rank correlations were calculated within OE1 and OE2 sows for residuals obtained after applying model 1 to the material. The variation in pregnancy rate between and within OE1 and OE2 sows was analysed using a chi square test.

The following levels of significance were used: n.s. $=\mathrm{p}>0.05 ; \quad *=\mathrm{p} \leq 0.05 ; \quad * *=\mathrm{p} \leq 0.01 ; * * *$ $=\mathrm{p} \leq 0.001$.

\section{Results}

Differences in production and fertility traits between OE1 and OE2 sows with an IWO of 3 to 8 days are presented in Table 1 .

There was a significant $(\mathrm{p}=0.048)$ difference in pregnancy rate between the 206 OE1 sows $(85.4 \%)$ and the 87 OE2 sows $(75.9 \%)$. The pregnant and non-pregnant OE1 sows differed significantly in weight and backfat losses during the first lactation period (model 2). The pregnant sows lost $33.0 \mathrm{~kg}$ and $8.8 \mathrm{~mm}$ of backfat, whereas the non-pregnant lost $27.2 \mathrm{~kg}$ and $7.0 \mathrm{~mm}$ of backfat. On the other hand there were no significant differences in IWO, weight or backfat at mating. Among the OE2 sows there were no significant differences observed between pregnant and non-pregnant sows. 
Table 4. Spearman rank correlations between residuals (using model 1) for IWO and second litter size in OE1 and OE2 sows with an IWO of 3-8 days.

\begin{tabular}{|c|c|c|c|c|}
\hline \multirow[t]{2}{*}{ Group of sows } & \multicolumn{4}{|c|}{ Second litter size } \\
\hline & At birth & Alive af birth & At 3 weeks & At 6 weeks \\
\hline OE1 & $\begin{array}{l}0.09^{\text {n.s. }} \\
(160)\end{array}$ & $\begin{array}{l}0.18 * \\
(129)\end{array}$ & $\begin{array}{l}0.16^{\text {n.s. }} \\
(128)\end{array}$ & $\begin{array}{l}0.17^{n . s} \\
(154)\end{array}$ \\
\hline OE2 & $\begin{array}{l}0.09^{\text {n.s. }} \\
(63)\end{array}$ & $\begin{array}{l}0.27^{\text {n.s. }} \\
(54)\end{array}$ & $\begin{array}{l}0.11^{\text {n.s. }} \\
(54)\end{array}$ & $\begin{array}{l}0.11 \text { n.s } \\
(50)\end{array}$ \\
\hline
\end{tabular}

Figures in brackets indicate the number of sows.

For abbreviations see Table 1.

The pregnancy rate among the OE1 sows decreased from a high level in sows mated on day 4 after weaning down to a relatively low level in sows mated on day 8 after weaning (Fig. 1). Mating from days 9 to 27 after weaning again resulted in high pregnancy rates. Among the OE2 sows with an IWO of 4 or 5 days, the pregnancy rates were 81.8 and 84.8 per cent, respectively. With an IWO of 6 to 7 days, the pregnancy rates decreased markedly to 60.0 and 66.7 per cent, respectively.

In a chi square test on pregnancy rate the sows were divided into 2 classes with an IWO of 3 5 and 6-8 days, respectively (Table 2 ). There were no significant differences in pregnancy rate between OE1 sows with an IWO of 3-5 days and 6-8 days. Among OE2 sows, on the other hand, the pregnancy rate was significantly lower in sows with an IWO of 6-8 days compared with 3-5 days. There were no significant differences in pregnancy rate between OE1 and OE2 sows having an IWO of 3-5 days. In sows having an IWO of 6-8 days, on the other hand, OE2 sows had a significantly lower pregnancy rate than OE1 sows.

There were no significant differences in pregnancy rate within OE1 and OE2 sows losing either $30 \mathrm{~kg}$ or less during the lactation or sows losing more than $30 \mathrm{~kg}$ (Table 2). Sows losing $30 \mathrm{~kg}$ or less during lactation were in one test split into 2 groups as follows: $1-\leq 20$ $\mathrm{kg} ; 2-21-30 \mathrm{~kg}$. For sows having a lactational weight loss of $20 \mathrm{~kg}$ or less, both OE1 and OE2 sows had high pregnancy rates $(81.0 \%$ and $84.6 \%$, respectively). In sows losing 21 to $30 \mathrm{~kg}$, on the other hand, the pregnancy rate in OE1 sows was 87.2 per cent and in OE2 sows 70.8 per cent.

OE2 sows having a first litter of more than 9 piglets, alive at birth, had a numerically but not significantly lower pregnancy rate than OE2 sows with fewer than 9 piglets (Table 2). If the first litter size was more than 9 piglets, the pregnancy rate was significantly higher in OE1 than in OE2 sows.

In total, 160 second litters (total number born) were recorded among the OE1 sows and 63 among the OE2 sows, all with an IWO of 3-8 days. The second litter size was significantly larger at birth in OE2 than in OE1 sows (Table 3). At weaning the difference was only 0.4 pigs per litter (n.s.)

There seemed to be a slight increase in second litter size in OE1 sows mated from day 4 to days 6 after weaning (Fig. 1). Mating from day 6 to 21 after weaning did not seem to change the subsequent litter size much, except for a decrease in OE1 sows mated on day 9 after weaning. Mating 
Table 5. Least squares means for second litter size in OE1 and OE2 sows with different weight losses during the 1st lactation (model 5), all with an IWO of 3-8 days.

\begin{tabular}{|c|c|c|c|c|c|}
\hline \multirow[t]{2}{*}{ 2nd litter size } & \multirow[t]{2}{*}{ Group of sows } & \multicolumn{4}{|c|}{ Weight loss during 1st lactation } \\
\hline & & $\leq 20 \mathrm{~kg}$ & $21-30 \mathrm{~kg}$ & $31-40 \mathrm{~kg}$ & $>40 \mathrm{~kg}$ \\
\hline \multirow[t]{2}{*}{ - at birth } & OE1 & $11.8^{\mathrm{a}}$ & $9.9^{b}$ & $11.0^{\mathrm{ab}}$ & $11.2^{\mathrm{ab}}$ \\
\hline & OE2 & $12.7^{\mathrm{ab}}$ & $11.8^{\mathrm{a}}$ & $13.2^{\mathrm{ab}}$ & $14.1^{\mathrm{b}}$ \\
\hline \multirow[t]{2}{*}{ - alive at birth } & OE1 & $10.3^{\mathrm{a}}$ & $9.0^{\mathrm{a}}$ & $9.9^{\mathrm{a}}$ & $10.3^{\mathrm{a}}$ \\
\hline & OE2 & $10.6^{\mathrm{a}}$ & $10.4^{\mathrm{a}}$ & $11.2^{\mathrm{a}}$ & $11.0^{\mathrm{a}}$ \\
\hline \multirow[t]{2}{*}{ - at 3 weeks } & OE1 & $9.8^{\mathrm{a}}$ & $8.6^{\mathrm{a}}$ & $9.2^{\mathrm{a}}$ & $9.6^{\mathrm{a}}$ \\
\hline & OE2 & $10.1^{\mathrm{a}}$ & $9.9^{\mathrm{a}}$ & $9.4^{\mathrm{a}}$ & $9.9^{\mathrm{a}}$ \\
\hline \multirow[t]{2}{*}{ - at 6 weeks } & OE1 & $9.8^{\mathrm{a}}$ & $8.4^{\mathrm{a}}$ & $9.2^{\mathrm{a}}$ & $9.4^{\mathrm{a}}$ \\
\hline & OE2 & $9.7^{\mathrm{a}}$ & $9.9^{\mathrm{a}}$ & $9.9^{\mathrm{a}}$ & $9.1^{\mathrm{a}}$ \\
\hline
\end{tabular}

ab Values with no superscript in common, within row, differ significantly $(\mathrm{p}<0.05)$.

For abbreviations see Table 1 .

on 22 to 27 days after weaning again seemed to increase the subsequent litter size.

Two different analyses were performed to demonstrate the influence of the IWO on the second litter size. In Table 3, the mean second litter size in sows with an IWO of 3-5 or 6-8 days is presented. The second litter size in OE1 sows was significantly larger with an IWO of 6-8 days compared with an IWO of 3-5 days. This difference also occurred in OE2 sows; however, it was smaller and not significant. The results from the Spearman correlation between the residuals for IWO and second litter size were positive, but significant only in OE1 sows for the number of piglets alive at birth (Table 4).

OE1 sows losing $20 \mathrm{~kg}$ or less during lactation had significantly larger second litters at birth than OE1 sows losing 21-30 kg, but not significantly larger than the sows losing more than $30 \mathrm{~kg}$ (Table 5). In the groups of sows losing more than $20 \mathrm{~kg}$, the second litter size at birth was larger in OE2 sows than in OE1 sows. There were no significant differences between OE1 and OE2 sows in second litter size alive at birth or at 3 and 6 weeks.

The overall mean value for the first and second litter size at birth in the 223 sows (OE1 +
OE2), with an IWO of 3-8 days, were 10.6 and 11.5 piglets, respectively. In Figure 2 , the mean values for the second litter size as well as for the difference between first and second litter size in sows with different first litter sizes are presented. There was a positive relationship between litter size in the first and second litter. Statistical analysis (model 6) showed that one piglet extra at birth in the first litter resulted in 0.25 extra piglets at birth in the second litter $(\mathrm{p}=0.001)$. A sow with a small first litter had, on average, a larger increase to the second litter size than sows with a large first litter. Thus there was a low probability for sows with a large first litter at birth to also have a large second litter (Fig. 2).

\section{Discussion}

\section{Statistics}

The analysed material was not primarily designed to study the influence of mating oestrus on subsequent litter size, and the statistical models must therefore include effects to be adjusted for. The effects of batch, selection line, and mating oestrus were included in all the models. Differences between OE1 and OE2 sows were found, for instance in weight loss 
during lactation and first litter size. These factors were therefore included in model 3 to adjust for that influence when only the effect of mating oestrus was intended to be shown. In model 4 , where the influence of IWO ( 2 classes) on subsequent litter size was studied, weight loss during lactation and first litter size were not included. We know from earlier studies by Sterning et al. (1990), based in part on the same sows as in the present study, that both weight loss and first litter size influence the IWO. Including these factors in the model would cancel out some of the variation in IWO. When analysing the effects of lactational weight loss and first litter size on the subsequent litter size, only classes of weight loss (model 5) and the regression of first litter size (model 6), respectively, were added to the models. The results on the effects of lactational weight loss and IWO (classes) on subsequent litter size are presented for each group of sows in order to demonstrate the importance of mating oestrus. When correlations between residuals for IWO and subsequent litter size (model 1) were analysed, Spearman rank correlations were used, as the IWO did not follow a normal distribution.

\section{Mating oestrus}

Both pregnancy rate and second litter size were influenced by the mating oestrus in the present study. The overall pregnancy rate for OE2 sows was significantly lower than for OE1 sows. This difference is not easily explained. Love (1979) found in a study on primiparous sows that sows mated more than 12 days after weaning (the majority of them were mated on their second oestrus) did not have a lower conception rate than sows mated on day 12 or earlier after weaning $(91.2 \%$ and $87.8 \%$, respectively). In a study to improve paritytwo litter, Morrow et al. (1989) also showed that sows mated on the first detected oestrus after 17 days post-weaning (weaning at 21 days) had a significantly higher farrowing rate $(87.2 \%)$ than sows mated at the first detected oestrus after weaning (74.8\%). A direct comparison with the present study, where only sows mated on the first or second oestrus after weaning were included, cannot be made. One explanaition of the low conception rate in OE2 sows in the present study could be that these sows had put on too much weight during the long period from weaning to mating with a feeding level of 4-5 $\mathrm{kg}$ per day. OE2 sows were heavier than OE1 sows at mating. Non-pregnant OE2 sows were, however, not heavier than pregnant OE2 sows. A study on feeding levels during the weaning to mating period by Brooks \& Cole (1972) showed that high feeding levels did not influence the conception rate negatively. However, most of these sows were probably mated on the first oestrus after weaning. Another explanation of the low pregnancy rate among OE2 sows in the present study could be that the rather heavy OE2 sows lost weight during early pregnancy, when the feed intake was decreased to $2.2 \mathrm{~kg}$ per day, and that this had a negative effect on the pregnancy rate. OE1 sows, on the other hand, probably increased their body weight slowly during gestation. More knowledge is needed about pregnancy rates in sows, both primiparous and pluriparous, who are mated on their second oestrus after weaning.

The litter size at birth, but not the number of piglets weaned, was significantly larger in OE2 sows than in OE1 sows in the present study. Both Love (1979) and Dyck (1974) found in studies on primiparous sows that the ovulation rate as well as embryo survival increased when the sows were mated on the second oestrus after weaning instead of on the first. Clowes et al. (1993) found that litter size (total number of piglets born) in parity 1 and 2 sows increased from 10.4 to 12.8 by breeding on the second 
oestrus after weaning. Wilson (1990) recommended delaying the mating of primiparous sows until their second oestrus. This recommendation is difficult to support fully with the present knowledge of pregnancy rates in sows mated on the second oestrus after weaning. The economic situation in Sweden for pig breeders shows that litter size must be increased by at least one weaned piglet, if no economic loss is going to result from delaying mating until the second oestrus after weaning. A cost-benefit analysis should also include the larger risk of not getting the sows pregnant if mated on the second oestrus after weaning compared to sows mated on the first oestrus.

\section{Interval from weaning to first oestrus}

The IWO influenced both the pregnancy rate and subsequent litter size in the present study. In the OE1 sows, the pregnancy rate was 92.3 per cent when the weaning to mating period was 4 days and then progressively decreased to 71.4 per cent on day 8 after weaning. On day 9 after weaning, the pregnancy rate was very high, although the subsequent litter size was low. In a study on primiparous and pluriparous sows in a research herd (Vesseur \& Kemp 1993), the farrowing rate increased progressively from 77.7 to 90.2 per cent with a weaning to mating period from 0 to 7 days. After that, the farrowing rate decreased to 63.5 per cent when the weaning to mating period was between 9 and 12 days. The lowest farrowing rate occurred concurrently with small, subsequent litter size. When the weaning to mating period was 13 to 18 days, the farrowing rate increased to 80.7 per cent. Leman (1990) also found a decrease in farrowing rate in primiparous and pluriparous sows with a weaning to mating interval around 9 days. This study was made on sows from 25 different North American farms. Wilson \& Dewey (1993) found in a study on primiparous and pluriparous sows from commercial herds that the farrowing rates in sows mated during a »less efficient « weaning to mating period (7-10 days) were lower than in sows mated during a more efficient period resulting in larger subsequent litter size. Even though the differences in the results between the studies are small, the pregnancy rates in primiparous and pluriparous sows seem to follow the same pattern. Worth mentioning from the present study are the differences in pregnancy rates in sows mated on the second oestrus after weaning with different IWOs. When primiparous sows with an IWO of 4 or 5 days were mated on the second oestrus, the pregnancy rate was rather high, but if the IWO was 6 or 7 days, the pregnancy rate decreased very clearly. More knowledge is needed about farrowing rates in primiparous and pluriparous sows with different IWOs mated on the second oestrus after weaning.

There was a significantly positive correlation (Spearman rank correlation) between residuals of IWO and subsequent litter size alive at birth in OE1 sows in the present study. When comparing the effect of IWO on second litter size in OE1 sows in the present study with the results of similar studies by Vesseur \& Kemp (1993) and Leman (1990) on primiparous and pluriparous sows, and by Dewey et al. (1993) on pluriparous sows, they were found to be almost the same. In all 4 studies there was a decrease in litter size when the weaning to mating period was around 9 days compared with a shorter or longer period. The decrese in the present study only occurred on day 9 after weaning, whereas in the other 3 studies, the decrease in litter size started earlier.

\section{Weight loss during lactation}

In the present study, the pregnancy rate was not particularly influenced by weight loss during lactation. No significant difference in pregnancy rate was found either in OE1 or OE2 sows 
which lost $30 \mathrm{~kg}$ or less compared with those who lost more than $30 \mathrm{~kg}$. In sows with a weight loss of more than $30 \mathrm{~kg}$ during lactation, the decrease in pregnancy rate if mating was delayed until the second oestrus after weaning was rather large, however, not significant. In the group of sows losing $20 \mathrm{~kg}$ or less there was no decrease in pregnancy rate if mating was delayed. Kirkwood et al. (1986), on the other hand, found that second parity sows receiving a low feeding level during lactation and losing $46 \mathrm{~kg}$ on average had a lower conception rate $(68.8 \%)$ than sows receiving a high feeding level and losing $18 \mathrm{~kg}(94.1 \%)$. Since all sows in the present study were fed according to their litter size resulting in great variation in weight loss during lactation, a direct comparison was not possible. King et al. (1982) found no significant relationships between loss of weight or fat during lactation and ovulation rate or subsequent litter size in a study on first litter sows in a commercial herd. In the present study, there was no significant difference in second litter size between OE1 sows losing $20 \mathrm{~kg}$ or less during lactation and OE1 sows losing more than $30 \mathrm{~kg}$. OE1 sows losing 21-30 kg during lactation, on the other hand, had a significantly smaller second litter at birth than OE1 sows losing $20 \mathrm{~kg}$ or less. Sows losing more than $30 \mathrm{~kg}$ in the present study probably had a large first litter resulting in a rather large weight loss. These sows probably had good reproductive performance and therefore also got a large second litter.

\section{First litter size}

In the present study there was little influence of the first litter size on the pregnancy rate. However, if the first litter size, alive at birth, was more than 9 piglets, the present study showed that the pregnancy rate decreased significantly if mating was delayed until the second oestrus after weaning. This result was not expected and is not easily explained. From an earlier study on primiparous sows (Sterning et al. 1990) we know that there is a relationship between litter size and weight loss during lactation. This relationship could explain the similarity in the effects on the pregnancy rate of litter size and of weight loss during lactation in the present study. Since the effect of litter size on the pregnancy rate was stronger than the effect of weight loss, it would be of interest to study both reproductive hormones and the level of stress hormones in sows with different first litter size. It is, however, very difficult to explain the decrease in the pregnancy rate when mating was delayed until the second oestrus after weaning in sows with large litters. It would be more likely to expect that both hormonal levels and the environment in the uterus had stabilised even more at the second oestrus after weaning than at the first oestrus. Further investigations on the pregnancy rate in primiparous sows mated on the first or the second oestrus after weaning and with different first litter size are required to give an explanation of the results found in the present study.

In the present study the mean litter size at birth increased from 10.6 in the first litter to 11.6 in the second litter. This result is in good agreement with the result from a study on litter sizes in 22 commercial Swedish herds (Lundeheim 1990), where the first litter size, alive at birth, was 9.7 and the second litter size was 10.5. The sows in that study were mainly LandraceYorkshire crosses. In a study on estimations of genetic parameters for reproductive traits in pigs, Johansson \& Kennedy (1985) found that the mean value for first litter size, total number born, in Swedish Yorkshire sows from 54 nucleus herds was 10.1 and the second litter size was 10.9. They also found a very strong genetic correlation between the first and second litter size at birth (0.87). The corresponding phenotypic correlation, on the other hand, was only 0.16 for litter size at birth.

The results from the present study showed that 
there was a small probability for sows with a large first litter to also have a large second litter. Morow et al. (1992) showed in a study on sows from 135 herds that a large first litter was the major determinant of fewer pigs being born alive in the second litter. This result is in agreement with the results from the present study.

\section{Conclusions}

It can be concluded from the results in the present study that:

- the pregnancy rate decreases when primiparous sows are mated on the second oestrus after weaning, compared with mating on the first oestrus, except in sows with an IWO of 35 days. Among "problem sows « having large weight losses during lactation ( $>30 \mathrm{~kg}$ ) or large first litters ( $>9$ piglets alive at birth), the pregnancy rate decreases more than for the rest of the sows if mating is delayed until the second oestrus after weaning. Further investigations designed to study the pregnancy rate in both primi and pluriparous sows, receiving the same feeding regime during lactation and after weaning, would be of great interest in order to determine whether such results would be in agreement with the results from the present study;

- the subsequent litter size, at birth, increases when mating is delayed until the second oestrus after weaning. However, the increase in litter size at weaning, when mating is delayed until the second oestrus, is very small. A longer IWO tends to give increased subsequent litter sizes, both in sows mated on the first and on the second oestrus after weaning. Large weight losses during lactation do not seem to decrease the subsequent litter size. The litter size increases from the first to the second litter, but the probability for sows with an extremely large first litter to also have an extremely large second litter is small.

\section{Acknowledgements}

This investigation was supported by The Farmer's Council for Information and Development. The authors wish to thank Prof. Stig Einarsson and Dr. Kjell Andersson for valuable advice and criticism. The authors also wish to thank the staff at the research station for very good management and cooperation, excellent technical assistance and for taking such good care of the animals. Special thanks to our technical assistant, Carola Jansson, for preparing all the basic data so that the statistical analyses of this study could be performed.

\section{References}

Bosu WTK, Edqvist L-E, Lindberg P, Martinsson K, Johansson EDB: The effect of various dosages of lynestrenol on plasma levels of oestrogen and progesterone during the menstrual cycle in rhesus monkey. Contraception 1976, 13, 677-684.

Brooks PH, Cole DJA: Studies in sow reproduction. 1 . The effect of nutrition between weaning and remating on the reproductive performance of primiparous sows. Anim. Prod. 1972, 15, 259-264.

Clowes EJ, Aherne FX, Foxcroft GR: Metabolic indicators in post-weaning sow fertility. Proceedings from Fourth Int. Conf. on Pig Reprod. 1993, Missouri, USA, abstract 78.

Dewey CE, Martin SW, Friendship RM, Wilson MR: The effects on litter size of previous lactation length and previous weaning-to-conception interval in Ontario swine. Prev. vet. Med. 1994, 18, 213-223.

Dyck $G W$ : The effects of stage of pregnancy, mating at the first and second estrus after weaning and level of feeding on fetal susrvival in sows. Can. J. Anim. Sci. 1974, 54, 277-285.

Johansson K, Kennedy BW: Estimation of genetic parameters for reproductive traits in pigs. Acta agric. scand. 1985, 35, 421-431.

King RH, Williams IH, Barker I: Reproductive performance of first litter sows in a commercial intensive piggery. Proceedings of the Australian Soc. of Anim. Prod. 1982, 14, 557-560.

Kirkwood RN, Baidoo SK, Aherne FX, Sather AP: The influence of level of weight and backfat change during lactation on the subsequent reproductive performance of sows. Agriculture and Forestry Bullentin (University of Alberta), Special Issue, 65th Annual Feeders' day Report 1986, 119-120.

Leman $A D$ : Best sows mate first 6 days after weaning. Int. Pigletter 1987, 5, 17-18.

Leman AD: Mate sows once 3-5 days after weaning. Int. Pigletter 1990, 8, 29-31. 
Love RJ: Reproductive performance of first litter sows. Vet. Rec. 1979, 104, 238-240.

Lundeheim $N$ : Normal variation i kullstorlek och grisningsintervall i RASP-besättningar. (Normal variation in litter size and farrowing intervals in commercial piglet producing herds.) Mimeo 6 p. 1990.

Morrow WEM, Leman AD, Williamson NB, Morison $R B$, Robinson RA: An epidemiological investigation of reduced second-litter size in swine. Prev. vet. Med. 1992, 12, 15-26.

Morrow WEM, Leman AD, Williamson NB, Moser $R$, Pijoan $C$ : Improving parity-two litter size in swine. J. Anim. Sci. 1989, 67, 1707-1713.

SAS Institute Inc.: SAS User's Guide. Statistic version 5. SAS Institute, Cary, N.C. 1985.

Stern S, Johansson K, Rydhmer L, Andersson K: Performance testing of pigs for lean tissue growth rate in a selection experiment with low and high protein diets. 1. Experimental design and efficiency of selection. Acta Agric. scand., Section A, Animal Sci. 1993, 43, 136-143.

Stern S, Lundeheim N, Andersson K: Performance and carcass traits after five generations of selection for lean tissue growth rate in pigs. In press. Animal Science 1995.

Sterning $M$, Rydhmer L, Einarsson S, Andersson K: Oestrous symptoms in primiparous sows 1 . Duration and intensity of external oestrous symptoms. Anim. Rep. Sci. 1994, 36, 305-314.

Sterning $M$, Rydhmer L, Eliasson L, Einarsson $S$, Andersson $K$ : A study on primiparous sows of the ability to show standing oestrus and to ovulate after weaning. Influences of loss of body weight and backfat during lactation and of litter size, litter weght gain and season. Acta vet. scand. 1990, 31, 227-236.

Vesseur PC, Kemp B: Importance of the weaning to oestrus interval for sow performance and identification of underlying factors. Proceedings from Fourth Int. Conf. on Pig Reprod. 1993, Missouri, USA, abstract 102.

Wilson M: Sow management to reduce boars, labor; increase production. International Pigletter 1990, 10, 13-14.

Wilson MR, Dewey CE: The associations between weaning-to-mating interval and sow productivity. Swine Health and Prod. 1993, 4, 10-15.

\section{Sammanfattning}

Faktorer som påverkar dräktighetsprocenten och den påföljande kullstorleken hos ungsuggor.

Dräktighetsprocenten och den påföljande kullstorleken studerades hos 332 ungsuggor, alla utfodrade efter samma norm under diperioden. Suggorna vägdes och ryggspäckets tjocklek mättes vid första grisningen, avvänjningen samt vid betäckningen. Brunstkontroll utfördes dagligen efter avvänjningen och blodprover för bestämning av plasma-progesteron togs regelbundet. Intervallet från avvänjning till första brunst (IWO) registrerades. Statistiska analyser baseras på suggor med IWO 3-8 dagar. Av dessa betäcktes 206 suggor (OE1) på sin första brunst efter avvänjningen och 87 (OE2) på sin andra.

Dräktighetsprocenten var $85,4 \%$ för OE1 suggor och $75,9 \%$ för OE2 suggor $(p=0,048)$. Det fanns ingen signifikant skillnad i dräktighetsprocent mellan OE1 suggor med IWO 3-5 respektive 6-8 dagar. OE2 suggor med IWO på 6-8 dagar hade däremot signifikant lägre dräktighetsprocent jämfört med OE2 suggor med IWO på 3-5 dagar. Det fanns ingen signifikant skillnad i dräktighetsprocenten mellan suggor som minskat mer än $30 \mathrm{~kg}$ under diperioden jämfört med de som minskat mindre än $30 \mathrm{~kg}$. Hos suggor med en första kull på mer än 9 levande födda grisar sjönk dräktighetsprocenten signifikant om de betäcktes på sin andra brunst efter avvänjningen jämfört med på den första.

OE2 suggor hade signifikant fler totalt födda $i$ andra kullen än OE1 suggor $(+2,0)$. Kullstorleken vid 6 veckor skiljde sej däremot ej signifikant $(+0,4)$. Korrelationen mellan IWO och andra kullens storlek var positiv. Den var dock bara signifikant hos OE1 suggor för IWO och antalet levande födda grisar. OE1 suggor som förlorade mindre än $20 \mathrm{~kg}$ under diperioden hade signifikant större antal födda $i$ andra kullen jämfört med OE1 suggor som förlorade $21-30 \mathrm{~kg}$ men inte större än de som förlorade mer än $30 \mathrm{~kg}$. En gris extra född i första kullen resulterade i 0,25 grisar extra i andra kullen. Sannolikheten för att suggor med en extremt stor första kull också skulle få en stor andra kull var låg.

(Received October 13, 1994; accepted May 24, 1995).

Reprints may be obtained from: M. Sterning, Department of Obstetrics and Gynaecology, Swedish University of Agricultural Sciences, P. O. Box 7039, S-750 07 Uppsala, Sweden. 
